\title{
Proteomic analysis identifies deregulated metabolic and oxidative-associated proteins in Italian intrahepatic cholangiocarcinoma patients
}

Giuliana Cavalloni ${ }^{1 * \dagger}$, Caterina Peraldo-Neia ${ }^{2 \dagger}$, Annamaria Massa ${ }^{1}$, Carlo Bergamini ${ }^{3}$, Alessandro Trentini ${ }^{3}$, Giovanni De Rosa ${ }^{4}$, Lorenzo Daniele ${ }^{4}$, Fabiola Ciccosanti ${ }^{5}$, Carlo Cervellati ${ }^{6}$, Francesco Leone ${ }^{7}$ and Massimo Aglietta ${ }^{1,8}$

\begin{abstract}
Background: Cholangiocarcinoma (CCA) is an aggressive disease with poor prognosis. A molecular classification based on mutational, methylation and transcriptomic features could allow identifying tailored therapies to improve CCA patient outcome. Proteomic remains partially unexplored; here, we analyzed the proteomic profile of five intrahepatic cholangiocarcinoma (ICC) derived from Italian patients undergone surgery and one normal bile duct cell line.

Methods: Proteome profile was investigated by using 2D electrophoresis followed by Mass Spectrometry (MS). To validate proteomic data, the expression of four overexpressed proteins (CAT, SOD, PRDX6, DBI/ACBP) was evaluated by immunohistochemistry in an independent cohort of formalin fixed, paraffin-embedded (FFPE) ICC tissues. We also compared proteomic data with those obtained by transcriptomic profile evaluated by microarray analysis of the same tissues.

Results: We identified 19 differentially expressed protein spots, which were further characterized by MS; 13 of them were up- and 6 were down-regulated in ICC. These proteins are mainly involved in redox processes (CAT, SODM, PRDX2, PRDX6), in metabolism (ACBP, ACY1, UCRI, FTCD, HCMS2), and cell structure and organization (TUB2, ACTB). CAT is overexpressed in $86 \%$ of patients, PRDX6 in 73\%, SODM in 100\%, and DBI/ACBP in 81\% compared to normal adjacent tissues. A concordance of 50\% between proteomic and transcriptomic data was observed.
\end{abstract}

Conclusions: This study pointed out that the impairment of the metabolic and antioxidant systems, with a subsequent accumulation of free radicals, might be a key step in CCA development and progression.

Keywords: Intrahepatic cholangiocarcinoma, Proteomics, Mass spectrometry, Metabolism, ROS

\footnotetext{
* Correspondence: giuliana.cavalloni@ircc.it

${ }^{\dagger}$ Giuliana Cavalloni and Caterina Peraldo-Neia contributed equally to this

work.

'Division of Medical Oncology, Candiolo Cancer Institute, FPO-IRCCS,

Candiolo, Torino, Italy

Full list of author information is available at the end of the article
}

(c) The Author(s). 2021 Open Access This article is licensed under a Creative Commons Attribution 4.0 International License, which permits use, sharing, adaptation, distribution and reproduction in any medium or format, as long as you give appropriate credit to the original author(s) and the source, provide a link to the Creative Commons licence, and indicate if changes were made. The images or other third party material in this article are included in the article's Creative Commons licence, unless indicated otherwise in a credit line to the material. If material is not included in the article's Creative Commons licence and your intended use is not permitted by statutory regulation or exceeds the permitted use, you will need to obtain permission directly from the copyright holder. To view a copy of this licence, visit http://creativecommons.org/licenses/by/4.0/ The Creative Commons Public Domain Dedication waiver (http://creativecommons.org/publicdomain/zero/1.0/) applies to the data made available in this article, unless otherwise stated in a credit line to the data. 


\section{Background}

Cholangiocarcinoma (CCA) is the second most common type of hepatobiliary cancer arising from the ductal epithelium of the biliary tree, either within the liver (intrahepatic cholangiocarcinoma, ICC) or from extrahepatic bile ducts (extrahepatic cholangiocarcinoma, ECC), which included perihilar and distal cholangiocarcinoma [1]. CCA incidence, pathogenesis and etiology differ not only among the subtypes, but also according to ethnicity, with peculiar genetic alterations and risk factors [2]. Globally, its incidence is higher in Asiatic Countries of the Pacific area, especially due to parasite infection, but the number of cases in Europe is increasing in the last 30 years [3]. As it concerns Italy, a retrospective study demonstrated that CCA incidence in the years 19882005 displayed an annual increment of 3-6\%, with highly increased rate and mortality for ICC compared to ECC [4]. A minority of patients had surgically resectable tumors at diagnosis, but the recurrence rate was higher than $50 \%$ within 5 years, since the diagnosis was often delayed [5]. The therapeutic approach for locally advanced or metastatic diseases is chemotherapy; the backbone is represented by Gemcitabine in association with platinum compounds, with a median overall survival of 11.7 months compared to 8.1 months of gemcitabine alone [6]. Unfortunately, patients developed resistance and disease progression occurred, making this pathology highly lethal. The molecular mechanisms and genetic steps underlying the pathogenesis of this tumor remain largely unknown; the heterogeneity of these tumors, the different etiology and risk factors involved in tumor development, complicate the identification of suitable molecular target and treatment options. In the last years, the importance to properly classify CCA emerged, considering the subtypes as different entities. Large-scale technologies, such as whole genome sequencing, RNA-seq, microarray and methylation arrays, highlighted the real need to distinguish either the subtypes or the intra- and inter-tumoral heterogeneity of CCA [7-9]. It is well-known that some mutations such as IDH1, BAP1, ARID1A, and FGFR2 rearrangements are typically enriched in ICC, while KRAS and TP53 in ECC [10]. In general, IDH1 and FGFR2 aberrations are associated with better prognosis, while KRAS and TP53 with worse outcome $[11,12]$. These data enforced the real need to treat ICC and ECC with tailored clinical approaches. Indeed, not only mutations, but also distinct patterns of epigenetic alteration profiling may differentiate ICC from ECC [13]. Moreover, recent studies demonstrated that a classification based on etiology and molecular aspects, such as methylation and copy number variations, is complementary and more useful than the subtypes classification alone [14].
Although there are lots of information about transcriptomic and mutational status, the proteomic profile of CCA remains only partially explored and is mainly associated to particular histotypes and/or ethnic origin, in turn strictly associated with risk factors.

In a study of Dos Santos and coll. a panel of 39 altered proteins involved in motility and actin cytoskeleton remodeling was found in an ICC case series compared to non-tumoral adjacent liver tissue [15]. In an Asiatic case series, Annexin A2, peroxiredoxin 1 and, ezrin-radixinmoesin-binding phosphoprotein 50 were identified as negative prognostic markers of CCA patients [16, 17]. Kristiansen and coll analyzed a case series of CCA, identifying some deregulated proteins, some of them never been associated with CCA arising and progression [18].

A recent review summarized the uniqueness molecular profile of liver fluke-associated CCA obtained by combining multi-omics approaches. Anti-inflammatory, immunomodulator/immunosuppressor, epidermal growth factor receptor or platelet-derived growth factor receptor inhibitors, multi-targeted tyrosine kinase inhibitor, IL6 antagonist, Nuclear Factor- $\mathrm{kB}$ inhibitor, histone modulator, proteasome inhibitor MetAP2 inhibitor, $1,25(\mathrm{OH})_{2} \mathrm{D}_{3}$ and cyclosporine A are suggested as targets for the treatment of this tumor subtype [19].

Recently, the comparison of 6 tumor and peritumoral ECC tissues identified 233 de-regulated proteins, one of them, the up-regulated PPP $3 C A$, is a strong predictor of poor survival [20].

To date, no proteome profiling has been explored in CCA derived from Italian patients. Here, we selected a homogeneous series of five ICC tumors obtained at the time of surgery. We processed them with 2-dimensional (2D) electrophoresis followed by mass spectrometry. The comparison of the proteomic profile with that obtained from a normal epithelial bile duct cell line provided precious information about the pathways potentially involved in tumor development and progression.

\section{Methods}

\section{Cell line and tumor samples}

Normal biliary epithelium cell line HIBEpiC (ScienCell Research Laboratories, Carlsbad, CA) was cultured in RPMI 1640 (Gibco, Carlsbad, CA, USA) medium supplemented with $10 \%$ fetal bovine serum (Sigma-Aldrich, St. Louis,MO, USA) and 1\% penicillin/streptomycin (Life Technologies Gathersburg, MD) at $37{ }^{\circ} \mathrm{C}$ and $5 \% \mathrm{CO} 2$. Tumor samples, 5 ICC fresh frozen (FF) tissues and 15 ICC formalin fixed, paraffin embedded (FFPE), were collected from ICC patients of Italian origin. Among FF ICC samples, 3 derived from females, 2 from males, with a median age at the time of diagnosis of 69 years. Tumor tissues used for the experiments were macrodissected from surgical samples, avoiding the inner (more 
necrotic) and the peripheral part of tumors (useful for margins evaluation in diagnosis). Biological material was obtained after informed consent, following institutional review board-approved protocols (001-IRCC-00IIS-10 FPO-IRCCS, Istituto di Ricovero e Cura a Carattere Scientifico Candiolo (TO), Italy).

\section{Proteomic analysis by 2 dimensional (2D) electrophoresis and mass spectrometry}

Five ICC and one normal epithelial bile duct cell line were subjected to proteomic analysis. Cells in culture were harvested and centrifuged at $400 \mathrm{~g}$ for $10 \mathrm{~min}$ at room temperature and washed once in $0.3 \mathrm{M}$ sucrose. The pellet was collected and treated with $100 \mu \mathrm{l} / 1 \times 10^{6}$ cells of lysis buffer (7 M Urea, $2 \mathrm{M}$ Thiourea, $4 \%$ CHAP S, $1 \mathrm{mM}$ EDTA, $2 \mathrm{mM}$ PMSF, $1 \mathrm{mM} \mathrm{NaF}, 40 \mathrm{mM}$ Tris, $\mathrm{pH} 9$ ) containing protease inhibitors (Halt Protease, Thermo Fisher Scientific, Cat. No. 78429). After vortexing 3 times for $10 \mathrm{~s}$, the cells were sonicated at $20 \mathrm{kHz}$ and $4{ }^{\circ} \mathrm{C}$ for pulses of $20 \mathrm{~s}$ with $20 \mathrm{~s}$ rest, for a total processing time of $3 \mathrm{~min}$. The suspension was incubated for $30 \mathrm{~min}$ on a rotating wheel and then centrifuged $30 \mathrm{~min}$ at $13000 \mathrm{xg}$ and $4{ }^{\circ} \mathrm{C}$ to remove particulate material. The supernatant was collected, placed in a clean microcentrifuge tube and centrifuged again $15 \mathrm{~min}$ at $13000 \mathrm{xg}$ and $4{ }^{\circ} \mathrm{C}$. At the end of the procedure, the supernatant was collected in a clean microcentrifuge tube and total protein content was determined with the Bradford assay.

For tissue samples, the procedure was slightly different. Samples were washed twice with sterile normal saline $(0.15 \mathrm{M} \mathrm{NaCl})$ under a laminar flow hood to remove contaminating hemoglobin and minced with a sterile scalpel. The small pieces were then transferred in a tube together with lysis buffer plus protease inhibitors in a weight $(\mathrm{g})$ to volume $(\mathrm{ml})$ ratio of 1:3. The samples were then subjected to homogenization by using a Polytron Homogenizer with brief cycles and on ice bath. At the end of the procedure, samples were transferred in clean microcentrifuge tubes and centrifuged for $30 \mathrm{~min}$ at $13000 \mathrm{xg}$ and $4{ }^{\circ} \mathrm{C}$. The supernatants were collected and subjected to another centrifugation at $15 \mathrm{~min}$ at 13000 $\mathrm{xg}$ and $4{ }^{\circ} \mathrm{C}$. Finally, supernatants were collected and assayed for total protein content with the Bradford assay.

All samples were processed separately and subjected to $2 \mathrm{D}$ electrophoresis as follow. Tree hundreds $\mu \mathrm{g}$ of proteins were subjected to isoelectric focusing (IEF) and separated on 2D SDS-PAGE on $12.5 \%$ polyacrylamide gels as described by Carcoforo and collaborators [21]. Gels were stained with colloidal Coomassie, and scanned with the Molecular Imager PharosFX System. The analysis was then performed using the ProteomWeaver 4 program (Bio-Rad, Hercules, CA, USA). Protein spots were automatically identified and manually adjusted if needed, then merged by Pair Matching or Multi Matching function in the software. Each spot was normalized by the total density of the gel to account for possible differences in stain procedure and amount of protein loaded. Differences in spot intensities between ICC and control were considered significant if the matched spots had a fold change $>2$ for the upregulated and $<0.5$ for downregulated signals and a $p$-value $<0.01$ in Student's t-test. Differentially expressed spots were then processed for mass spectrometry-based peptide identification.

Briefly, gel fragments were washed in $100 \mathrm{mM}$ ammonium bicarbonate and $50 \%(\mathrm{v} / \mathrm{v}) \mathrm{ACN}$, dehydrated by incubation in $100 \%(\mathrm{v} / \mathrm{v}) \mathrm{ACN}$ and rehydrated in $50 \mathrm{mM}$ ammonium bicarbonate containing $4 \mathrm{ng} / \mu \mathrm{L}$ of trypsin; $50 \mathrm{mM}$ ammonium bicarbonate was added following digestion overnight at $37^{\circ} \mathrm{C}$. Tryptic peptides were concentrated with ZipTip mC18 pipette tips (Millipore) and co-eluted onto the MALDI target in $1 \mu \mathrm{L}$ of $\alpha$-cyano-4hydroxycinnamic acid matrix $(5 \mathrm{mg} / \mathrm{mL}$ in $50 \% \mathrm{ACN}$, $0.1 \%$ TFA). MALDI-MS and MALDI-MS/MS were carried out with a 5800 MALDI TOF/TOF Analyzer (Sciex, Ontario-Canada) essentially as described by Carcoforo and collaborators [21] and detailed in supplementary methods (Additional file 1).

\section{Immunohistochemistry}

Catalase expression was evaluated in 15 ICC tumors. Briefly, tumor sections were deparaffinized and rehydrated with graded of ethanol. The epitope retrieval was obtained using Antigen Retrieval Citrate solution pH 6.0 and exposed to 2 min cycles at $700 \mathrm{~W}$ in a microwave oven. Endogenous peroxidase activity was blocked with $0.3 \%$ hydrogen peroxide for $10 \mathrm{~min}$, followed by treatment with V-block for 30 min (Dako, Santa Clara, CA). Sections were incubated for $2 \mathrm{~h}$ in a moist chamber at room temperature with the specific primary antibody for CAT (mouse anti Human CAT, 1:100, Santa Cruz) diluted in TBS 1X. Then, slides were rinsed twice in buffer and then incubated with the detection system solution, a Dextran polymer conjugated to horseradish peroxidase, for $30 \mathrm{~min}$. The final reaction was visualized using 3,3'diaminobenzidine in a buffer/hydrogen peroxide solution for $3 \mathrm{~min}$. Finally, sections were counterstained with Harris's hematoxylin, dehydrated, and mounted in DPX (Sigma Aldrich, Saint Louis, MO, USA). Eleven ICC tumors (for five samples, the biological material is not available and one more tumor tissue was added) were stained for PRDX6, SODM, and DBI (Aurogene). Briefly, after rehydration, the endogenous peroxidases were blocked in a solution of methanol and hydrogen peroxides $(0.3 \%)$ for $30 \mathrm{~min}$. The epitope retrieval was obtained using Antigen Retrieval Citrate solution pH 6.0 (Dako) and exposed to 2 cycles of 5 min each at $850 \mathrm{~W}$ in a microwave oven. The saturation of non-specific sites 
was performed with a solution of $5 \%$ Normal Goat Serum (Dako) in TBS-Tween (0.3\%)-Triton (0.1\%) for 1 $\mathrm{h}$ in moist chamber at room temperature. Then, slides were incubated $\mathrm{O} / \mathrm{N}$ at $4{ }^{\circ} \mathrm{C}$ with the appropriate primary antibodies at the following dilutions: 1:50 for rabbit polyclonal PRDX6, 1:200 for mouse monoclonal SODM and rabbit polyclonal DBI in the saturation solution. After rinsing, slides were incubated with anti-RabbitHRP (for DBI and PRDX6) and with anti-Mouse-HRP (for SODM) for $1 \mathrm{~h}$ at room temperature. The final reaction was visualized using DAB+ Substrate Chromogen System (Dako) for $3 \mathrm{~min}$. Finally, sections were counterstained with Harris's hematoxylin, dehydrated, and mounted in DPX (Sigma Aldrich). Immunohistochemical results were evaluated by two different pathologists (LD and GDR). For CAT and ACBP/DBI expression, the intensity of the reaction was classified using a three grade system: weak positivity (a weak intensity cytoplasmatic staining observed in $<30 \%$ of the cells), intermediate positivity (a moderate intensity cytoplasmatic staining observed in $>30 \%$ of the tumor cells), and strong positivity (a strong intensity cytoplasmatic staining observed in $>30 \%$ of the tumor cells). For SODM the percentage of positive tumor cells was evaluated on a scale of $0-3$ ( 0 no staining, $1+<10 \%, 2+11-30 \%, 3+$ $31-50 \%, 4+>50 \%)$. For PRDX6 the staining was scored as the product of the staining intensity (on a scale of 0 2: negative $=0$, low $=1$, high $=2$ ) and the percentage of cells stained (on a scale of 0-3:0 = zero, $1=1-25 \%, 2=$ $26-50 \%, 3=51-100 \%)$ resulting in scores on a scale of $0-5$.

\section{External dataset for gene expression profiling}

We extrapolated the gene expression data of the 5 ICC tumors used for proteomic analysis from the dataset GSE107102. They were included in a bigger cohort of ICC tumors analyzed in our previous work [22]. Material and methods used are previously deeply described in Peraldo-Neia et al. [22]. Gene Expression Profiling Interactive analysis GEPIA (http://gepia.cancer-pku.cn) database and the Human Protein Atlas (https://www. proteinatlas.org) database were used to verify the expression at mRNA and protein levels, respectively, of differentially expressed targets selected by proteomic analysis.

\section{Results}

\section{Analysis of differentially expressed proteins}

Five tissue samples of ICC patients and normal control (normal biliary epithelium cell line) were run on 2-D GE to investigate differentially expressed protein in tumor compared to normal tissue. Approximately 580 spots were detected in 2-D GE, as shown in Table 1, with an average of 218 spots/gel.
Table 1 Number of spots detected for each sample and control cells

\begin{tabular}{ll}
\hline Sample & Number of spots \\
\hline Control cells & 233 \\
Sample 1 & 224 \\
Sample 2 & 197 \\
Sample 3 & 227 \\
Sample 4 & 218 \\
Sample 5 & 212 \\
\hline
\end{tabular}

Proteins of each sample were run on separate gels. Figure 1 showed a representative image of gels for one sample (A) and for the normal bile duct cell line (B), while the images for the other samples run in different gels are collected in Additional file 2.

The analysis indicated that 19 proteins, (one of them, $\mathrm{HBB}$, was identified by two peptides) were differentially expressed within the two groups. In particular, 13 spots were upregulated ( $>2$ fold) and 6 were downregulated $(<0.5$ fold $)$ in ICC samples.

Mass Spectrometry was used to identify the selected 19 protein spots, which is reported in Table 2.

A consistent part of upregulated proteins $(23.5 \%)$ in ICC tissues, is related to redox biology. In particular CAT, PRDX2, PRDX6 and SODM are highly expressed compared to normal biliary epithelium cell line (10.6, 3.7, 3.7 and 3.5 fold, respectively). Other proteins with an increased expression were related to metabolism (Acyl-CoA-binding protein, Aminoacylase-1, Cytochrome b-c1 complex subunit Rieske, mitochondrial), cell structure (cytoplasmic Actin 2), signaling (Retinal dehydrogenase 1), oxygen transport (Hemoglobin subunit beta) and DNA binding (Histone H4). Downregulated proteins (fold change between 0.45-0.18) are involved in cell metabolism (HydroxymethylglutarylCoA synthase, mitochondrial Protein disulfide-isomerase and Formimidoyltransferase-cyclodeaminase), cytoskeleton organization (Tubulin alpha-1B chain and Tropomyosin alpha-3 chain), and heat shock protein (Stress-70 protein, mitochondrial).

\section{Immunohistochemistry validation of redox and metabolism processes}

In order to validate proteomic data, we selected four among the up-regulated proteins found by previous analysis, all associated to overrepresented above mentioned processes; we evaluated CAT $(n=15)$, SODM, PRDX6 and DBI/ACBP ( $n=11$ for the last three proteins) protein expression by IHC in an independent case series of archival tissue samples derived from ICC Italian patients. Table 3 summarized the score staining for each protein.

CAT was detected in all tumor tissue samples with different staining score: 2 out of $15(13.3 \%)$ were weakly 


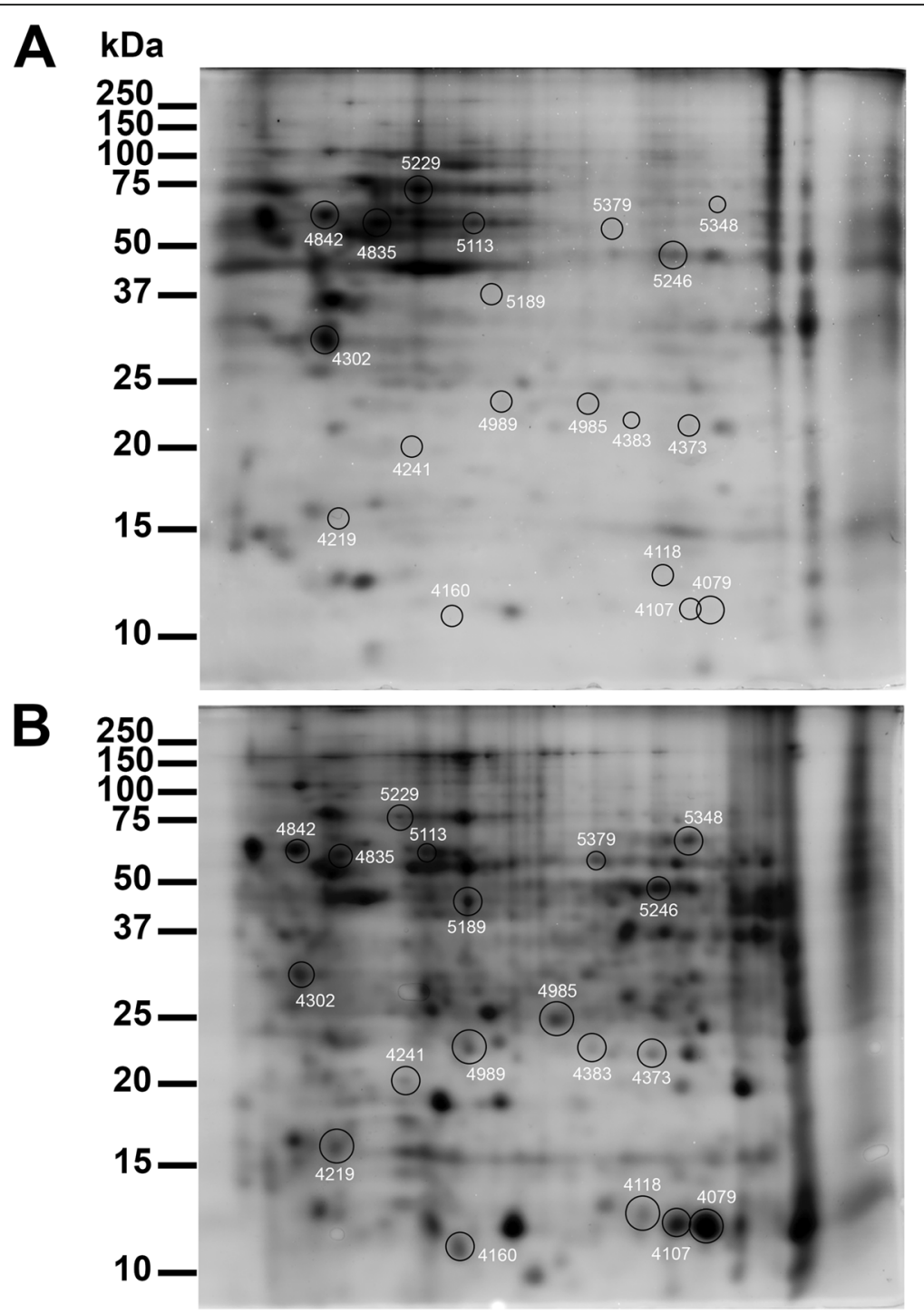

Fig. 1 Representative 2D gel images indicating the differential spots in normal cells (A) and ICC samples (B). Black circles indicate up-regulated spots. Immobilized pH gradient 3-10 NL strips were used for the first dimension, 12.5\% polyacrylamide gels were used for the second dimension

positive, 11 out of $15(73.3 \%)$ were positive, and 2 out of 15 (13.3\%) were strongly positive. SODM is overexpressed in all tumor tissues, 8 out of 11 tumors $(73 \%)$ are classified as $4+$ and 3 out of 11 tumors $(27 \%)$ as $3+$. PRDX6 is expressed in 8 out 11 samples (73\%); of them, 5 are classified as $2+, 2$ as $3+$, one as $4+$ and 3 were negative. For these two proteins, the expression was mainly weak or absent in the normal surrounding bile duct. DBI/ACBP was expressed in all the samples with different intensities, 2 with weak, 5 with intermediate, and 4 strong intensities.

In all tested samples, the normal counterpart expressed lower levels of the proteins examined. Figure 2 represents different score staining for CAT in ICC samples, while representative IHC images of tumor sections compared to the normal counterparts for ACBP/DBI, PRDX6, and SODM are shown in Additional file 3.

We exploited the Human Protein Atlas database to retrieve more information about protein expression. CCA is included in the "liver cancer" disease, and for each protein selected, a different number of CCA samples were available. Six out of 8 expressed CAT, one with strong intensity. SODM was highly expressed in 3 out of 4 CCA available, PRDX6 in 6 out of 7 CCAs (four with strong-moderate expression), and for ACBP/DBI only three samples were available, 2 of them with weak expression and one moderate. Additional file 4 summarized data obtained for all the differentially expressed proteins by using Protein Atlas database. 
Table 2 Up- and down-regulated proteins identified by proteomic analysis and MS in ICC compared to control

\begin{tabular}{|c|c|c|c|c|c|c|}
\hline Acc. $n^{\circ}$ UniProtKB & $\begin{array}{l}\text { SPOT } \\
\text { ID }\end{array}$ & Protein name & Pathway & $\begin{array}{l}\text { Fold } \\
\text { Change }\end{array}$ & $\begin{array}{l}\text { Sequence } \\
\text { coverage (\%) }\end{array}$ & $\begin{array}{l}\text { Number of Unique } \\
\text { Peptides (C.I. 95\%) }\end{array}$ \\
\hline \multicolumn{7}{|l|}{ Upregulated proteins } \\
\hline $\begin{array}{l}\text { sp|P07108|ACBP } \\
\text { HUMAN }\end{array}$ & 4160 & Acyl-CoA-binding protein & $\begin{array}{l}\text { Metabolism } \\
\text { (lipids) }\end{array}$ & 14.3 & 72.4 & 7 \\
\hline$\frac{\text { sp|P68871|HBB_ }}{\text { HUMAN }}$ & 4079 & Hemoglobin subunit beta & Oxygen transport & 14.9 & 89.8 & 18 \\
\hline $\begin{array}{l}\text { Sp|P68871|HBB } \\
\underline{\text { HUMAN }}\end{array}$ & 4107 & Hemoglobin subunit beta & Oxygen transport & 14.4 & 89.8 & 18 \\
\hline $\begin{array}{l}\text { sp|P04040|CATA } \\
\text { HUMAN }\end{array}$ & 5348 & Catalase & Redox homeostasis & 10.6 & 21.3 & 6 \\
\hline $\begin{array}{l}\text { sp|Q03154|ACY1_ } \\
\text { HUMAN }\end{array}$ & 5189 & Aminoacylase-1 & $\begin{array}{l}\text { Metabolism } \\
\text { (amino acids) }\end{array}$ & 7.1 & 47.3 & 11 \\
\hline $\begin{array}{l}\text { sp|P47985|UCRI_ } \\
\text { HUMAN }\end{array}$ & 4383 & $\begin{array}{l}\text { Cytochrome b-c1 complex } \\
\text { subunit Rieske, mitochondrial }\end{array}$ & Metabolism & 5.6 & 20.8 & 4 \\
\hline $\begin{array}{l}\text { sp|P63261|ACTG_ } \\
\text { HUMAN }\end{array}$ & 4219 & Actin, cytoplasmic 2 & Cytoskeleton & 4.8 & 29.1 & 5 \\
\hline $\begin{array}{l}\text { sp|P30041|PRDX6_ } \\
\text { HUMAN }\end{array}$ & 4985 & Peroxiredoxin- 6 & Redox homeostasis & 3.7 & 64.7 & 10 \\
\hline $\begin{array}{l}\text { sp|P32119|PRDX2 } \\
\text { HUMAN }\end{array}$ & 4241 & Peroxiredoxin-2 & Redox homeostasis & 3.7 & 36.4 & 8 \\
\hline $\begin{array}{l}\text { sp|Q96IU4|ABHEB_ } \\
\text { HUMAN }\end{array}$ & 4989 & Protein ABHD14B & $\begin{array}{l}\text { Cytosolic sulfonation of small } \\
\text { molecules }\end{array}$ & 3.7 & 47.1 & 5 \\
\hline $\begin{array}{l}\text { Sp|P04179|SODM_ } \\
\text { HUMAN }\end{array}$ & 4373 & $\begin{array}{l}\text { Superoxide dismutase [Mn], } \\
\text { mitochondrial }\end{array}$ & Redox homeostasis & 3.5 & 39.2 & 6 \\
\hline $\begin{array}{l}\text { sp|P62805|H4_ } \\
\text { HUMAN }\end{array}$ & 4118 & Histone $\mathrm{H} 4$ & DNA binding & 3.0 & 17.5 & 2 \\
\hline $\begin{array}{l}\text { sp|P00352|AL1A1_ } \\
\text { HUMAN }\end{array}$ & 5379 & Retinal dehydrogenase 1 & Cell signaling & 3.0 & 24 & 8 \\
\hline \multicolumn{7}{|c|}{ Downregulated proteins } \\
\hline $\begin{array}{l}\text { sp|P54868|HMCS2 } \\
\text { HUMAN }\end{array}$ & 5246 & $\begin{array}{l}\text { Hydroxymethylglutaryl-CoA } \\
\text { synthase, mitochondrial }\end{array}$ & Metabolism & 0.45 & 29.9 & 6 \\
\hline $\begin{array}{l}\text { sp|P07237|PDIA1_ } \\
\text { HUMAN }\end{array}$ & 4842 & Protein disulfide-isomerase & Metabolism & 0.33 & 32.5 & 9 \\
\hline $\begin{array}{l}\text { sp|O95954|FTCD_ } \\
\text { HUMAN }\end{array}$ & 5113 & $\begin{array}{l}\text { Formimidoyltransferase- } \\
\text { cyclodeaminase }\end{array}$ & Metabolism & 0.29 & 39.7 & 8 \\
\hline $\begin{array}{l}\text { sp|P38646|GRP75 } \\
\text { HUMAN }\end{array}$ & 5229 & Stress-70 protein, mitochondrial & Heat shock response & 0.23 & 15.5 & 7 \\
\hline $\begin{array}{l}\text { sp|P68363|TBA1B_ } \\
\text { HUMAN }\end{array}$ & 4835 & Tubulin alpha-1B chain & Cytoskeleton & 0.22 & 26.8 & 7 \\
\hline $\begin{array}{l}\text { sp|P06753|TPM3 } \\
\text { HUMAN }\end{array}$ & 4302 & Tropomyosin alpha-3 chain & Cytoskeleton & 0.18 & 27.4 & 5 \\
\hline
\end{tabular}

Fold change represents the ratio between the mean percentage relative volume $(\% \mathrm{~V})(\% \mathrm{~V}=\mathrm{V}($ single spot) $/ \mathrm{N}($ total spot $))$ determined in ICC and the normal sample. Score refers to the sum of the Mascot ion scores of all of the peptides that were identified for a given protein. Sequence coverage is the \% of aminoacidic sequences identified by MS. Number of Unique Peptides is the number of peptides matching the identified proteins

Comparison between proteomic and transcriptomic data In a previous work [22], we analyzed the gene expression profiling of 13 ICC (including the five samples used for proteomic analysis) fresh frozen tumors comparing them with a dataset including normal bile ducts (GSE107102). From this dataset, we extrapolated and reanalyzed data of the five samples of interest to investigate if there was a correspondence in terms of expression between protein and transcriptomic data. As shown in Table 4, considering protein expression as reference, and applying a $\log F C$ threshold of $|0.5|$ for mRNA expression, we have a protein-mRNA expression concordance of 50\%, 5 out of 12 among up- and 4 out of 6 among downregulated targets in tumors compared to normal tissue.

We exploited GEPIA database to compare the expression of these targets between tumor and normal tissue at 
Table 3 Score of catalase immunostaining on ICC and normal counterpart tissues

\begin{tabular}{|c|c|c|c|c|c|c|c|c|}
\hline \multirow{2}{*}{$\begin{array}{l}\text { Sample } \\
\text { Sample }\end{array}$} & \multicolumn{2}{|l|}{ CAT } & \multicolumn{2}{|l|}{ SODM } & \multicolumn{2}{|l|}{ DBI } & \multicolumn{2}{|l|}{ PRDX6 } \\
\hline & Tumor area & $\begin{array}{l}\text { Normal } \\
\text { area }\end{array}$ & $\begin{array}{l}\text { Tumor } \\
\text { area }\end{array}$ & Normal area & Tumor area & Normal area & $\begin{array}{l}\text { Tumor } \\
\text { area }\end{array}$ & Normal area \\
\hline 1 & positive & negative & NA & NA & NA & NA & NA & NA \\
\hline 2 & weakly positive & negative & NA & NA & NA & NA & NA & NA \\
\hline 3 & positive & negative & NA & NA & NA & NA & NA & NA \\
\hline 4 & weakly positive & negative & NA & NA & NA & NA & NA & NA \\
\hline 5 & positive & negative & $4+$ & Weak positivity & Strong positivity & $\begin{array}{l}\text { Intermediate } \\
\text { positivity }\end{array}$ & negative & negative \\
\hline 6 & positive & negative & $4+$ & Weak positivity & $\begin{array}{l}\text { Intermediate } \\
\text { positivity }\end{array}$ & Weak positivity & $2+$ & negative \\
\hline 7 & positive & negative & $3+$ & Weak positivity & $\begin{array}{l}\text { Intermediate } \\
\text { positivity }\end{array}$ & Weak positivity & $2+$ & negative \\
\hline 8 & $\begin{array}{l}\text { strongly } \\
\text { positive }\end{array}$ & negative & NA & NA & NA & NA & NA & NA \\
\hline 9 & positive & negative & $3+$ & Weak positivity & Strong positivity & $\begin{array}{l}\text { Intermediate } \\
\text { positivity }\end{array}$ & $3+$ & $\begin{array}{l}\text { Weak } \\
\text { positivity }\end{array}$ \\
\hline 10 & positive & negative & $4+$ & $\begin{array}{l}\text { Intermediate } \\
\text { positivity }\end{array}$ & $\begin{array}{l}\text { Intermediate } \\
\text { positivity }\end{array}$ & Weak positivity & $2+$ & negative \\
\hline 11 & positive & negative & $4+$ & negative & Weak positivity & Weak positivity & $4+$ & $\begin{array}{l}\text { Weak } \\
\text { positivity }\end{array}$ \\
\hline 12 & positive & negative & $4+$ & negative & Weak positivity & Weak positivity & negative & negative \\
\hline 13 & $\begin{array}{l}\text { strongly } \\
\text { positive }\end{array}$ & negative & $3+$ & Weak positivity & $\begin{array}{l}\text { Intermediate } \\
\text { positivity }\end{array}$ & Weak positivity & $2+$ & negative \\
\hline 14 & positive & negative & $4+$ & $\begin{array}{l}\text { Intermediate } \\
\text { positivity }\end{array}$ & $\begin{array}{l}\text { Intermediate } \\
\text { positivity }\end{array}$ & $\begin{array}{l}\text { Intermediate } \\
\text { positivity }\end{array}$ & negative & negative \\
\hline 15 & positive & negative & $4+$ & Weak positivity & Strong positivity & $\begin{array}{l}\text { Intermediate } \\
\text { positivity }\end{array}$ & $3+$ & $\begin{array}{l}\text { Weak } \\
\text { positivity }\end{array}$ \\
\hline 16 & NA & NA & $4+$ & Weak positivity & Strong positivity & Weak positivity & $2+$ & negative \\
\hline
\end{tabular}

NA not available

mRNA levels; 36 ICC and 9 normal tissues are included in the analysis (TCGA dataset). Boxplot for each targets were summarized in Additional file 5 and the concordance between TCGA data and our GEP analysis and TCGA data and proteomic analysis was reported. Results are only partially comparable, mainly due to the small number of samples analyzed in each case series. No association between targets expression and survival was found using TCGA dataset (Additional file 6), with the exception of PRDX2, whose high expression in

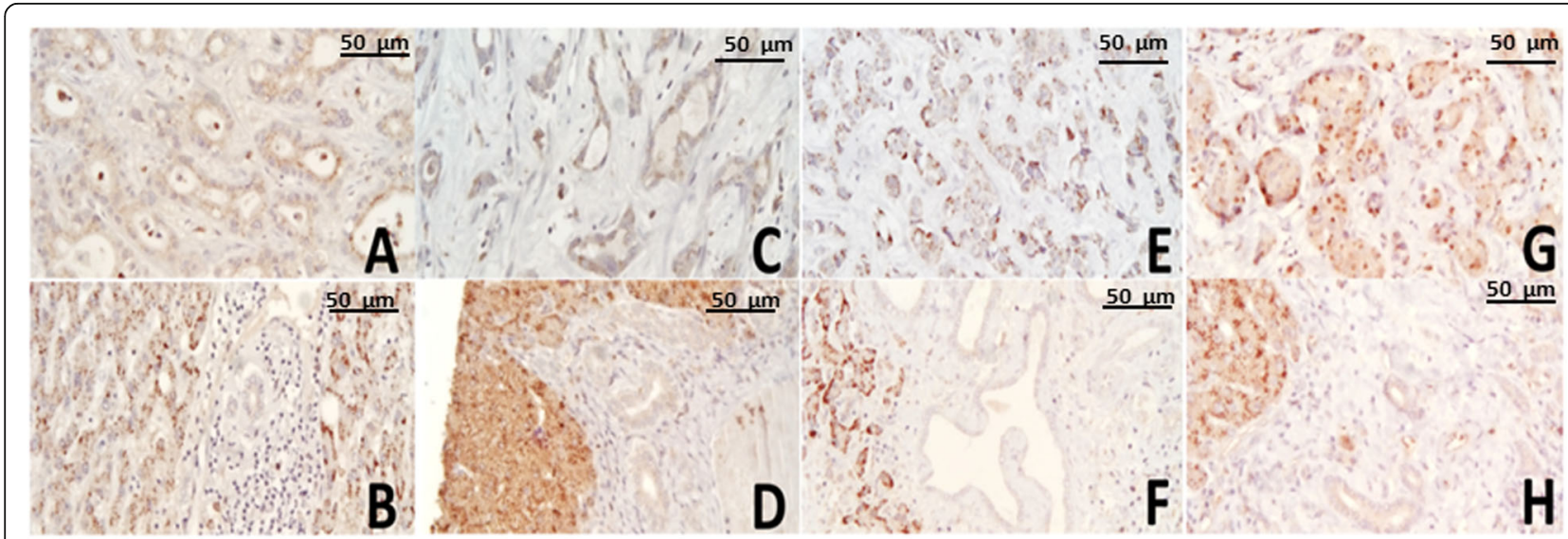

Fig. 2 Representative CAT immunostaining images of ICC tissues. A-C-E-G showed ICC tissues with different CAT staining (A: weakly positive; C: positive; E-G: highly positive). B-D-F-H showed the corresponding normal surrounding tissues. Images were acquired at 40X 
Table 4 Comparison of protein and mRNA expression in ICC samples

\begin{tabular}{lllll}
\hline Protein ID & Protein Name & Expression in ICC vs normal & Gene Name & Log2FC in ICC vs normal \\
\hline P07108 & ACBP & UP & DBI & 0.530 \\
P68871 & UBB & UP & HBB & -0.343 \\
P04040 & CATA & UP & CAT & $-2-284$ \\
Q03154 & ACY1 & UP & ACY1 & -0.22 \\
P47985 & UP & UQCRFS1 & 0.094 \\
P63261 & UCRI & UP & ACTG & -1.213 \\
P30041 & ACTG & UP & PRDX6 & -0993 \\
P32119 & PRDX6 & UP & PRDX2 & 0.747 \\
Q961U4 & PRDX2 & UP & CIB1 & 1.103 \\
P04179 & ABHEB & UP & SOD2 & 1.968 \\
P62805 & SODM & HIST1H4A & 2.571 \\
P00352 & H4 & UP & ALDH1A1 & -3.260 \\
P54868 & ALIA1 & UP & HMGCS2 & -1809 \\
P07237 & HMCS2 & DOWN & P4HB & 0.018 \\
O95954 & PDIA1 & DOWN & FTCD & -3.798 \\
P38646 & FTCD & DOWN & HSPA9 & -2.673 \\
P68363 & GRP75 & DOWN & TUBA1B & -0.939 \\
P06753 & TBA1B & DOWN & TPM3 & 0.936 \\
\hline
\end{tabular}

associated with poor disease free survival $(p=0.01)$ and of ALDH1A1, whose low expression is associated with poor disease free survival $(p=0.03)$.

\section{Discussion}

In the last decade, the identification of putative targets for CCA treatment has become challenging. To date, mutational and transcriptomic profiles, as well as methylation status and fusions assessment, are deeply investigated and many progresses in terms of classification and identification of prognostic biomarkers have been made. It is well-known that all the above-mentioned alterations are strictly associated to ethnicity and etiology and we assume the same behavior for proteomic profile. This, together with the increasing incidence of ICC in Italy and the lack of effective therapies prompted us to analyze the protein expression profile of a small cohort of ICC derived from Italian patients. The first limit of this study is the small number of patients available, but it can be considered a training analysis, which suggests potential targets suitable for therapies to be tested in a validation set. Nevertheless, this study pointed out the impairment of the antioxidant system, with a subsequent accumulation of free radicals. In particular, the main process in which the deregulated proteins are involved is the redox pathway.

It is well established that metabolic processes play a key role in tumor progression. Here, we evidenced an up-regulation of ACBP1, confirmed also in the independent case series by IHC, which is already described in other tumor types, especially in glioblastoma and astrocytoma [23, 24]. In physiological conditions, its role is the maintenance of lipid metabolism, steroidogenesis, and peptide hormone release; when overexpressed, it supports tumor growth by controlling the availability of long chain fatty acids which are processed by mitochondria with a fatty oxidation reaction [25]. ACBP1/DBI silencing induces cell senescence, reduces cell proliferation, delays tumor initiation and prolongs survival in in vivo model. Moreover, due to its role as adaptor to microenvironment changes, it seems to promote the cancer stem cell niche during neurogenesis [26].

$\mathrm{HBB}$ is involved in oxygen metabolism. High expression was detected in breast cancer, in particular in bone metastasis [27]. Authors suggested a positive correlation between $\mathrm{HBB}$ expression and ability of disseminating tumor cells in other organs, indicating a more aggressive phenotype [28]. This data is also confirmed by the work of Zheng and coll. in which HBB is abundantly expressed in circulating tumor cells of breast and prostate cancer patients and its expression is closely detected in circulating tumor cells (CTC), and not in primary tumors [29]. CAT and SODM, both involved in antioxidant processes, are up-regulated in our cohort of ICC patients. Loilome and collaborators demonstrated, in an O. viverrini hamster cholangiocarcinoma model, that both enzymes are highly expressed during cholangiocarcinogenesis, while there is a decreased expression when 
tumors are well established [30]. The same group demonstrated that both proteins are expressed at different levels in CCA tissues, but they are also expressed in normal bile ducts and hepatocytes [31]. Interestingly, its activity is dramatically reduced in CCA compared to normal bile ducts. In contrast, high expression and activity of antioxidant enzymes, among them SODM and CAT, are found in a cholangiocytes hydrogen peroxide resistant cell line obtained by gradual and continuous exposition to hydrogen peroxides. This cell line had a higher proliferation rate and a more aggressive phenotype compared to the parental one; thus, it may be a suitable model of cholangiocarcinogenesis [32]. In our validation case series, we found that CAT protein is expressed at different levels in cancer tissues, but not in normal adjacent ones. A recent work demonstrated that the presence of variants in genes associated to oxidative stress pathway may affect the response to chemotherapy. Moreover, CAT overexpression inhibits proliferation in vitro of CCA in vitro models and promotes cisplatin and doxorubicin-induced antitumor activity, while low levels of CAT induce resistance to these chemotherapeutic agents [33]. We analyzed the expression of another protein strictly associated with CAT, SODM, found overexpressed by proteomic data. The same trend was revealed in the independent case series tested by IHC.

$\mathrm{ACY} 1$ is found up-regulated in different tumor types. Literature data demonstrated that ACY1 knockdown in colorectal cancer cells inhibits proliferation and increases apoptosis, becoming an interesting target to explore [34]. In contrast, ACY1 is a putative tumor suppressor in small cell lung cancer and hepatocarcinoma $[35,36]$.

The impairment of UQCRFS1, involved in mitochondrial stability, electron transport driving oxidative phosphorylation, expression was described in gastric cancers where it is frequently amplified and associated to tumor progression [37]. Opposite results are shown in clear cell renal carcinoma; UQCRFS1 is downregulated, probably due to a DNA hypermethylation of that region [38]. ACTB expression is high in tumor tissues and cell lines; its deregulation in tumors is associated to loss of polarization and major invasiveness and metastatic potential [39], also described in metastatic breast cancer [40]. PRDX2 is already described as overexpressed in CCA tissues compared to the normal surrounding ones [40], while PRDX6 is overexpressed in the inflammation process induced by Clonorchis Siniensis [41]. The upregulation of both PRDX2 and PRDX6 is described in many tumors and correlated with invasiveness, migration, drug resistance and enhancing stem cell properties, in particular in NSCLC, colorectal cancer, and esophageal carcinoma [42-45]. From IHC analysis, we found that about $73 \%$ of ICC expressed higher levels of PRDX6 compared to the normal adjacent tissues, in line with published data. PRDX6 overexpression is also associated with poor prognosis and overall survival in ovarian cancer [46]. HIST1H4A resulted highly up-regulated in exosomes released by NSCLC [47]. A recent study conducted on CCA patients showed that high expression of ALDH1A1 correlated with a more favorable prognosis [48]; in many studies, ALDH1A1 is a cancer stem cell marker and a suitable target for therapy and only its activity is associated to worse prognosis $[49,50]$.

Another limit of this study is the use of normal immortalized colangiocytes cell line as control in MS experiments, instead of the most appropriate normal biliary tissue; in fact, the cell line lacks the microenvironment, the cellular components usually present in tumor surrounding tissues, actually weakening and potentially impairing our findings. However, the proteins identified in our study were validated in an independent cohort of ICC tissues comparing their expression with the normal surrounding tissues, albeit on a limited number of cases.

Globally, this study, even if conducted on a small number of samples, provided precious information about the role of oxidative and metabolic processes in CCA progression, suggesting also that they may be good targets for therapy in CCA. Combining therapies able to tip the balance towards the anti-cancer activity of these pathways with standard chemotherapy could be an alternative approach in CCA treatment. Recently, it was demonstrated that the administration of metformin in association to Cisplatin enhances the oxidative stress mediated cell death pathway, hence increasing the efficacy of Cisplatin alone [50]. Moreover, these pathways may have a potential as prognostic biomarkers in serum. Uchida and collaborators demonstrated that an increase concentration of reactive oxygen metabolites and a decrease level of antioxidative metabolites in serum are associated to poor outcome in CCA patients, suggesting the importance of such processes in tumor progression [51]. The complexity of metabolic and oxidative pathways deserves tailored studies to clarify their role in cancer development, progression and drug resistance.

\section{Abbreviations}

CCA: Cholangiocarcinoma; ICC: Intrahepatic cholangiocarcinoma; MS: Mass spectrometry; CAT: Catalase; SOD: Superoxide dismutase;

PRDX6: Peroxiredoxin 6; DBI/ACBP: Diazepam Binding Inhibitor, Acyl-CoA

Binding Protein; FFPE: Formalin fixed, paraffin-embedded; ECC: Extrahepatic cholangiocarcinoma; iTRAQ: Isobaric tags for relative and absolute quantitation; FF: Fresh frozen; IEF: Isoelectric focusing; DTT: Dithiothreitol; 
ACN: Acetonitrile; TBS: Tris buffered saline; 2-D GE: 2 dimentional gel electrophoresis; FC: Fold change

\section{Supplementary Information}

The online version contains supplementary material available at https://doi. org/10.1186/s12885-021-08576-z.

Additional file 1. Additional methods. MS spectra data acquisition.

Additional file 2. $2 \mathrm{D}$ gel images of single ICC samples. The molecular weight on the left side corresponds to (from top to bottom): $250 \mathrm{kDa}$, $150 \mathrm{kDa}, 100 \mathrm{kDa}, 75 \mathrm{kDa}, 50 \mathrm{kDa}, 37 \mathrm{kDa}, 25 \mathrm{kDa}, 20 \mathrm{kDa}, 15 \mathrm{kDa}$, $10 \mathrm{kDa}$.

Additional file 3. Representative images of $\mathrm{IHC}$ for DBI, PRDX6, and SODM. DBI staining in tumor tissue A) in normal counterpart B); PRDX6 staining in tumor tissue $\mathrm{C}$ ) in normal counterpart D); SODM staining in tumor tissue E) in normal counterpart F). All the images are captured with 20X.

Additional file 4. Protein expression data obtained from The Protein Atlas database.

Additional file 5. Box plots representing the expression at mRNA level of all the targets identified by proteomics obtained using GEPIA. Red box: ICC; grey box: normal tissues.

Additional file 6. Kaplan Meier curves (Overall survival and Disease free survival) obtained using GEPIA exploiting mRNA expression data of TCGA.

\section{Acknowledgements}

CPN was supported by "Compagnia di San Paolo".

\section{Authors' contributions}

GC and CPN conceived the study, performed the experiments and wrote the first article draft; $C B$ revised the article; $A M$ revised the article and funding acquisition; AT, FC, and CC performed proteomics experiments and analyzed data; GDR and LD performed and analyzed IHC; FL and MA conceived the study and revised the article draft. All the authors read and approved the manuscript.

\section{Funding}

This work was supported by FPRC 5xmille 2015 Ministero Salute "Cancer ImGen" and by Fondazione Roche-Bando per la ricerca 2019.

\section{Availability of data and materials}

The datasets used and/or analyzed during the current study are available from the corresponding author on reasonable request.

\section{Declarations}

Ethics approval and consent to participate

This study was approved by the institutional Ethics committee (FPO-IRCCS, Candiolo Cancer Institute, Candiolo, Torino).

The study was carried out in accordance with the guidelines included the approved protocol (PROFILING protocol: "Prospective study for the determination of molecular profiles of patients affected by tumors resistant to target therapies." Ethic code: 001-IRCC-00IIS-10, version 6.1, 23 June 2016). Informed consent was obtained from all subjects/patients included in this study. All methods were performed in accordance with the relevant guidelines and regulations (Declaration of Helsinki). Cell line used in the present study did not require ethics approval for their use.

\section{Consent for publication}

Not applicable.

\section{Competing interests}

The authors declare that they have no competing interests

\section{Author details}

'Division of Medical Oncology, Candiolo Cancer Institute, FPO-IRCCS, Candiolo, Torino, Italy. ${ }^{2}$ Cancer Genomics Lab, Fondazione Edo ed Elvo Tempia, Biella, Italy. ${ }^{3}$ Department of Chemistry and Pharmaceutical Sciences, University of Ferrara, Ferrara, Italy. ${ }^{4}$ Pathology Unit, AO Ordine Mauriziano,
Torino, Italy. ${ }^{5}$ Department of Epidemiology, Preclinical Research, and Advanced Diagnostics, National Institute for Infectious Diseases, IRCCS 'Lazzaro Spallanzani', Rome, Italy. ${ }^{6}$ Department of Morphology, Surgery \& Experimental Medicine, University of Ferrara, Ferrara, Italy. ${ }^{7}$ Department of Oncology, ASL BI, Ospedale degli Infermi di Biella, Ponderano, BI, Italy. ${ }^{8}$ Department of Oncology, University of Turin, Torino, Italy.

Received: 20 November 2020 Accepted: 9 July 2021

Published online: 28 July 2021

\section{References}

1. Rizvi S, Gores GJ. Pathogenesis, diagnosis, and management of cholangiocarcinoma. Gastroenterology. 2013;145(6):1215-29. https://doi. org/10.1053/j.gastro.2013.10.013.

2. Rizvi S, Khan SA, Hallemeier CL, Kelley RK, Gores GJ. Cholangiocarcinoma evolving concepts and therapeutic strategies. Nat Rev Clin Oncol. 2018; 15(2):95-111. https://doi.org/10.1038/nrclinonc.2017.157.

3. Khan SA, Tavolari S, Brandi G. Cholangiocarcinoma: epidemiology and risk factors. Liver Int. 2019;39(Suppl 1):19-31. https://doi.org/10.1111/liv.14095.

4. Banales JM, Cardinale V, Carpino G, Marzioni M, Andersen JB, Invernizzi P, et al. Expert consensus document: cholangiocarcinoma: current knowledge and future perspectives consensus statement from the European network for the study of cholangiocarcinoma (ENS-CCA). Nat Rev Gastroenterol Hepatol. 2016;13(5):261-80. https://doi.org/10.1038/nrgastro.2016.51.

5. Valle JW, Lamarca A, Goyal L, Barriuso J, Zhu AX. New horizons for precision medicine in biliary tract cancers. Cancer Discov. 2017;7(9):943-62. https:// doi.org/10.1158/2159-8290.CD-17-0245.

6. Valle JW, Furuse J, Jitlal M, Beare S, Mizuno N, Wasan H, et al. Cisplatin and gemcitabine for advanced biliary tract cancer: a meta-analysis of two randomised trials. Ann Oncol. 2014;25(2):391-8. https://doi.org/10.1093/a nnonc/mdt540.

7. Ruzzenente A, Fassan M, Conci S, Simbolo M, Lawlor RT, Pedrazzani C, et al. Cholangiocarcinoma heterogeneity revealed by multigene mutational profiling: clinical and prognostic relevance in surgically resected patients. Ann Surg Oncol. 2016;23(5):1699-707. https://doi.org/10.1245/s10434-0155046-6.

8. Simbolo M, Fassan M, Ruzzenente A, Mafficini A, Wood LD, Corbo V, et al. Multigene mutational profiling of cholangiocarcinomas identifies actionable molecular subgroups. Oncotarget. 2014;5(9):2839-52. https://doi.org/10.1 8632/oncotarget.1943.

9. Yang B, House MG, Guo M, Herman JG, Clark DP. Promoter methylation profiles of tumor suppressor genes in intrahepatic and extrahepatic cholangiocarcinoma. Mod Pathol. 2005;18(3):412-20. https://doi.org/10.1038/ modpathol.3800287.

10. Roos E, Soer EC, Klompmaker S, Meijer LL, Besselink MG, Giovannetti E, et al. Crossing borders: a systematic review with quantitative analysis of genetic mutations of carcinomas of the biliary tract. Crit Rev Oncol Hematol. 2019; 140:8-16. https://doi.org/10.1016/j.critrevonc.2019.05.011.

11. Goyal L, Govindan A, Sheth RA, Nardi V, Blaszkowsky LS, Faris JE, et al. Prognosis and Clinicopathologic features of patients with advanced stage Isocitrate dehydrogenase (IDH) mutant and IDH wild-type intrahepatic cholangiocarcinoma. Oncologist. 2015;20(9):1019-27. https://doi.org/10.1 634/theoncologist.2015-0210.

12. Mahipal A, Tella SH, Kommalapati A, Anaya D, Kim R. FGFR2 genomic aberrations: Achilles heel in the management of advanced cholangiocarcinoma. Cancer Treat Rev. 2019;78:1-7. https://doi.org/10.1016/ j.ctrv.2019.06.003.

13. Fouassier L, Marzioni M, Afonso MB, Dooley S, Gaston K, Giannelli G, et al. Signalling networks in cholangiocarcinoma: molecular pathogenesis, targeted therapies and drug resistance. Liver Int. 2019;39(Suppl 1):43-62. https://doi.org/10.1111/liv.14102.

14. Jusakul A, Cutcutache I, Yong CH, Lim JQ, Huang MN, Padmanabhan N, et al. Whole-genome and Epigenomic landscapes of etiologically distinct subtypes of cholangiocarcinoma. Cancer Discov. 2017;7(10):1116-35. https:// doi.org/10.1158/2159-8290.CD-17-0368.

15. Dos Santos A, Court M, Thiers V, Sar S, Guettier C, Samuel D, et al. Identification of cellular targets in human intrahepatic cholangiocarcinoma using laser microdissection and accurate mass and time tag proteomics. Mol Cell Proteomics. 2010;9(9):1991-2004. https://doi.org/10.1074/mcp.M11 0.000026 . 
16. Yonglitthipagon P, Pairojkul C, Chamgramol Y, Loukas A, Mulvenna J, Bethony J, et al. Prognostic significance of peroxiredoxin 1 and ezrinradixin-moesin-binding phosphoprotein 50 in cholangiocarcinoma. Hum Pathol. 2012;43(10):1719-30. https://doi.org/10.1016/j.humpath.2011.11.021.

17. Silsirivanit A, Sawanyawisuth K, Riggins GJ, Wongkham C. Cancer biomarker discovery for cholangiocarcinoma: the high-throughput approaches. J Hepatobiliary Pancreat Sci. 2014;21(6):388-96. https://doi org/10.1002/jhbp.68.

18. Kristiansen TZ, Harsha HC, Grønborg M, Maitra A, Pandey A. Differential membrane proteomics using 180-labeling to identify biomarkers for cholangiocarcinoma. J Proteome Res. 2008;7(11):4670-7. https://doi.org/10.1 021/pr800215n.

19. Vaeteewoottacharn K, Seubwai W, Bhudhisawasdi V, Okada S, Wongkham S. Potential targeted therapy for liver fluke associated cholangiocarcinoma. J Hepatobiliary Pancreat Sci. 2014;21(6):362-70. https://doi.org/10.1002/jhbp.65.

20. Tang Z, Yang Y, Zhang J, Fu W, Lin Y, Su G, et al. Quantitative proteomic analysis and evaluation of the potential prognostic biomarkers in cholangiocarcinoma. J Cancer. 2019;10(17):3985-99. https://doi.org/10.7150/ jca.29354.

21. Carcoforo P, Ura B, Mischiati C, Squerzanti M, Lanzara V, Cervellati C, et al. Comparative proteomic analysis of ductal breast carcinoma demonstrates an altered expression of chaperonins and cytoskeletal proteins. Mol Med Rep. 2013;7(5):1700-4. https://doi.org/10.3892/mmr.2013.1375.

22. Peraldo-Neia C, Ostano P, Cavalloni G, Pignochino Y, Sangiolo D, De Cecco $L$, et al. Transcriptomic analysis and mutational status of $I D H 1$ in paired primary-recurrent intrahepatic cholangiocarcinoma. BMC Genomics. 2018; 19(1):440. https://doi.org/10.1186/s12864-018-4829-0.

23. Duman C, Yaqubi K, Hoffmann A, Acikgöz AA, Korshunov A, Bendszus M, et al. Acyl-CoA-Binding Protein Drives Glioblastoma Tumorigenesis by Sustaining Fatty Acid Oxidation. Cell Metab. 2019;30(2):274-289.e275.

24. Miettinen $H$, Kononen J, Haapasalo $H$, Helén $P$, Sallinen $P$, Harjuntausta $T$, et al. Expression of peripheral-type benzodiazepine receptor and diazepam binding inhibitor in human astrocytomas: relationship to cell proliferation. Cancer Res. 1995;55(12):2691-5.

25. Swinnen JV, Alen P, Heyns W, Verhoeven G. Identification of diazepambinding inhibitor/acyl-CoA-binding protein as a sterol regulatory elementbinding protein-responsive gene. J Biol Chem. 1998;273(32):19938-44. https://doi.org/10.1074/jbc.273.32.19938.

26. Dumitru I, Neitz A, Alfonso J, Monyer H. Diazepam Binding Inhibitor Promotes Stem Cell Expansion Controlling Environment-Dependent Neurogenesis. Neuron. 2017;94(1):125-137.e125.

27. Ponzetti M, Capulli M, Angelucci A, Ventura L, Monache SD, Mercurio C, et al. Non-conventional role of haemoglobin beta in breast malignancy. $\mathrm{Br} J$ Cancer. 2017;117(7):994-1006. https://doi.org/10.1038/bjc.2017.247.

28. Capulli M, Angelucci A, Driouch K, Garcia T, Clement-Lacroix P, Martella F, et al. Increased expression of a set of genes enriched in oxygen binding function discloses a predisposition of breast cancer bone metastases to generate metastasis spread in multiple organs. J Bone Miner Res. 2012; 27(11):2387-98. https://doi.org/10.1002/jbmr.1686.

29. Zheng Y, Miyamoto DT, Wittner BS, Sullivan JP, Aceto N, Jordan NV, et al. Expression of $\beta$-globin by cancer cells promotes cell survival during bloodborne dissemination. Nat Commun. 2017;8(1):14344. https://doi.org/10.1038/ ncomms14344.

30. Loilome W, Kadsanit S, Namwat N, Techasen A, Puapairoj A, Dechakhamphu $A$, et al. Impaired antioxidant enzyme activity and increased DNA repair enzyme expression in hamster liver tissues related to cholangiocarcinoma development. Asian Pac J Cancer Prev. 2012;13(Suppl):59-64.

31. Loilome W, Kadsanit S, Muisook K, Yongvanit P, Namwat N, Techasen A, et al. Imbalanced adaptive responses associated with microsatellite instability in cholangiocarcinoma. Oncol Lett. 2017;13(2):639-46. https://doi. org/10.3892/ol.2016.5477

32. Thanan R, Techasen A, Hou B, Jamnongkan W, Armartmuntree N, Yongvanit $P$, et al. Development and characterization of a hydrogen peroxide-resistant cholangiocyte cell line: a novel model of oxidative stress-related cholangiocarcinoma genesis. Biochem Biophys Res Commun. 2015:464(1): 182-8. https://doi.org/10.1016/j.bbrc.2015.06.112.

33. Zhan M, Wang H, Xu SW, Yang LH, Chen W, Zhao SX, et al. Variants in oxidative stress-related genes affect the chemosensitivity through Nrf2mediated signaling pathway in biliary tract cancer. EBioMedicine. 2019;48: 143-60. https://doi.org/10.1016/j.ebiom.2019.08.037.
34. Yu B, Liu X, Cao X, Zhang M, Chang H. Study of the expression and function of ACY1 in patients with colorectal cancer. Oncol Lett. 2017;13(4):2459-64. https://doi.org/10.3892/ol.2017.5702.

35. Miller YE, Minna JD, Gazdar AF. Lack of expression of aminoacylase-1 in small cell lung cancer. Evidence for inactivation of genes encoded by chromosome 3p. J Clin Invest. 1989;83(6):2120-4. https://doi.org/10.1172/ JCl114125.

36. Wei X, Li J, Xie H, Ling Q, Wang J, Lu D, et al. Proteomics-based identification of the tumor suppressor role of aminoacylase 1 in hepatocellular carcinoma. Cancer Lett. 2014;351(1):117-25. https://doi.org/1 0.1016/j.canlet.2014.05.001.

37. Jun KH, Kim SY, Yoon JH, Song JH, Park WS. Amplification of the UQCRFS1 gene in gastric cancers. J Gastric Cancer. 2012;12(2):73-80. https://doi.org/1 0.5230/jgc.2012.12.2.73

38. Ellinger J, Gromes A, Poss M, Brüggemann M, Schmidt D, Ellinger N, et al. Systematic expression analysis of the mitochondrial complex III subunits identifies UQCRC1 as biomarker in clear cell renal cell carcinoma. Oncotarget. 2016;7(52):86490-9. https://doi.org/10.18632/oncotarget.13275.

39. Guo C, Liu S, Wang J, Sun MZ, Greenaway FT. ACTB in cancer. Clin Chim Acta. 2013;417:39-44. https://doi.org/10.1016/j.cca.2012.12.012.

40. Lu X, Gao C, Liu C, Zhuang J, Su P, Li H, et al. Identification of the key pathways and genes involved in HER2-positive breast cancer with brain metastasis. Pathol Res Pract. 2019;215(8):152475. https://doi.org/10.1016/j. prp.2019.152475.

41. Pak JH, Son WC, Seo SB, Hong SJ, Sohn WM, Na BK, et al. Peroxiredoxin 6 expression is inversely correlated with nuclear factor-KB activation during Clonorchis sinensis infestation. Free Radic Biol Med. 2016;99:273-85. https:// doi.org/10.1016/j.freeradbiomed.2016.08.016.

42. Xu J, Su Q, Gao M, Liang Q, Li J, Chen X. Differential expression and effects of Peroxiredoxin-6 on drug resistance and Cancer stem cell-like properties in non-small cell lung Cancer. Onco Targets Ther. 2019;12:10477-86. https:// doi.org/10.2147/OTT.S211125.

43. Huang WS, Huang CY, Hsieh MC, Kuo YH, Tung SY, Shen $\mathrm{CH}$, et al. Expression of PRDX6 correlates with migration and invasiveness of colorectal Cancer cells. Cell Physiol Biochem. 2018;51(6):2616-30. https://doi. org/10.1159/000495934.

44. He Y, Xu W, Xiao Y, Pan L, Chen G, Tang Y, et al. Overexpression of Peroxiredoxin 6 (PRDX6) promotes the aggressive phenotypes of esophageal squamous cell carcinoma. J Cancer. 2018;9(21):3939-49. https:// doi.org/10.7150/jca.26041.

45. LV Z, Wei J, You W, Wang R, Shang J, Xiong Y, et al. Disruption of the cMyc/miR-200b-3p/PRDX2 regulatory loop enhances tumor metastasis and chemotherapeutic resistance in colorectal cancer. J Transl Med. 2017;15(1): 257. https://doi.org/10.1186/s12967-017-1357-7.

46. Li S, Hu X, Ye M, Zhu X. The prognostic values of the peroxiredoxins family in ovarian cancer. Biosci Rep. 2018;38(5). https://doi.org/10.1042/BSR20180667.

47. Pan D, Chen J, Feng C, Wu W, Wang Y, Tong J, et al. Preferential Localization of MUC1 Glycoprotein in Exosomes Secreted by Non-Small Cell Lung Carcinoma Cells. Int J Mol Sci. 2019;20(2). https://doi.org/10.3390/ijms20020323

48. Padthaisong S, Thanee M, Namwat N, Phetcharaburanin J, Klanrit $\mathrm{P}$, Khuntikeo $N$, et al. Overexpression of a panel of cancer stem cell markers enhances the predictive capability of the progression and recurrence in the early stage cholangiocarcinoma. J Transl Med. 2020;18(1):64. https://doi. org/10.1186/s12967-020-02243-w.

49. Yoshino J, Akiyama Y, Shimada S, Ogura T, Ogawa K, Ono H, et al. Loss of ARID1A induces a stemness gene ALDH1A1 expression with histone acetylation in the malignant subtype of cholangiocarcinoma. Carcinogenesis. 2020;41(6):734-42. https://doi.org/10.1093/carcin/bgz179.

50. Tomita H, Tanaka K, Tanaka T, Hara A. Aldehyde dehydrogenase $1 A 1$ in stem cells and cancer. Oncotarget. 2016;7(10):11018-32. https://doi.org/10.1 8632/oncotarget.6920.

51. Uchida D, Takaki A, Ishikawa H, Tomono Y, Kato H, Tsutsumi K, et al. Oxidative stress balance is dysregulated and represents an additional target for treating cholangiocarcinoma. Free Radic Res. 2016;50(7):732-43. https:// doi.org/10.3109/10715762.2016.1172071.

\section{Publisher's Note}

Springer Nature remains neutral with regard to jurisdictional claims in published maps and institutional affiliations. 